\title{
The Change in Mental Health Status of Indonesian Health Care Migrant Worker in Japan
}

\section{Perubahan Status Kesehatan Jiwa Pekerja Kesehatan Indonesia di Jepang}

\author{
Susiana Nugraha*, Sumihisa Honda**, Yuko Hirano**
}

\author{
*Public Health Study Program, School of Health Sciences Jenderal Achmad Yani, Cimahi, Indonesia, **Graduate \\ School of Biomedical Science, Health Sciences Division, Nagasaki University, Nagasaki, Japan
}

\begin{abstract}
Under the Japan - Indonesia Economic Partnership Agreement, more than 1,000 of Indonesian health care workers have migrated to Japan. Social adjustment during the process of migration is linked to mental health changes. This study aimed to figure out the strongest predictor that influences the change in mental health status as a result of migration. Baseline data were collected in Jakarta in 2013 during pre-departure orientation. Follow-up study was conducted one year after the study participants migrated to Japan in 2014. Using longitudinal design, this study employed 92 participants consisting of nurse and certified care worker candidates. The multiple linear regression analysis was conducted to figure out the predictors that influence the change in mental health status. The prediction model expected to explain $39.9 \%$ of the change in mental health status, $p$ value $<0.01$, while $\operatorname{sex}(\beta=0.201$, $p$ value $<0.05)$, economic conditions in pre-migration $(\beta=-0.200, p$ value $<0.05)$, and the socio cultural adaptation competency $(\beta=-0.238$, $p$ value $<0.05)$. This finding assumed that female candidates and those who have economic constraint in pre-migration stage, and those who have declining in socio-cultural adaptation competency tend to have lower mental health one year after the migration.
\end{abstract}

Keywords: Candidate, certified care worker, Japan - Indonesia Economic Partnership Agreement, mental health, nurse

\begin{abstract}
Abstrak
Melalui kerja sama kemitraan di bidang ekonomi antara Jepang - Indonesia, sampai saat ini terdapat lebih dari 1.000 pekerja kesehatan Indonesia bekerja di Jepang sejak tahun 2008. Sejumlah penelitian tentang migrasi ke luar negeri menunjukkan bahwa penyesuaian sosial selama proses migrasi berkaitan dengan kesehatan jiwa. Penelitian ini bertujuan untuk mengetahui faktor-faktor yang memengaruhi perubahan status kesehatan jiwa akibat migrasi. Data dasar dikumpulkan di Jakarta tahun 2013 pada saat orientasi sebelum keberangkatan, dan studi lanjutan dilakukan satu tahun setelah peserta berangkat ke Jepang tahun 2014. Dengan menggunakan desain longitudinal, penelitian ini melibatkan 92 orang yang terdiri dari perawat dan pendamping lansia bersertifikasi. Analisis regresi linier berganda dilakukan untuk mengetahui prediktor yang memengaruhi perubahan status kesehatan jiwa. Model regresi menunjukkan $39,9 \%$ perubahan status kesehatan mental dipengaruhi oleh jenis kelamin $(\beta=0,201$, nilai $p<0,05)$, kondisi ekonomi sebelum migrasi $(\beta=-0,200$, nilai $p<0,05)$, dan skor socio-cultural adaptation competency $(\beta=-0,238$, nilai $p<0,05)$. Temuan ini dapat diasumsikan bahwa kandidat perempuan dan mereka yang memiliki kesulitan ekonomi pada saat pra-migrasi, serta mereka yang telah mengalami penurunan dalam kompetensi adaptasi sosio-kultural cenderung memiliki kesehatan jiwa yang lebih rendah satu tahun setelah migrasi.
\end{abstract}

Kata kunci: Kandidat, pekerja perawat bersetifikat, Japan - Indonesia Economic Partnership Agreement, kesehatan jiwa, perawat

How to Cite:Nugraha S, Honda S, Hirano Y. The change in mental health status of Indonesian health care migrant worker in Japan. Kesmas: National Public Health Journal. 2017; 12 (2): 53-59. (doi:10.21109/kesmas. v12i2.1698)
Correspondence: Susiana Nugraha, School of Health Sciences Jenderal Achmad Yani Cimahi, Terusan Jenderal Sudirman Street, Cimahi, West Java, Phone: +6222-6631622,e-mail: susiana.nugraha@stikesayani.ac.id

Received: August 29th 2017

Revised: October $11^{\text {th }} 2017$

Accepted: October $12^{\text {th }} 2017$ 


\section{Introduction}

International migration has become a social phenomenon in current mobile world. Boosted by the forces of globalization, development and demographic changes, migration has become a defining feature of the economic, social, and political life in a mobile world. The United Nation Foundation for Population Activity (UNFPA). ${ }^{1}$ reported that 232 million people $(3.2 \%)$ of the world's population lived outside their country of origin in 2013.1 Nurse migration has become one of those phenomena that occurs in the context of increasing global mobility and growing competition for scarce skills, including skills required in the health care sector. ${ }^{2}$

The migration of Indonesian health care workers in Japan began under the bilateral agreement launched in 2008, namely the Japan - Indonesia Economic Partnership Agreement (JIEPA). This program allows Indonesian health care workers to work as nurses and certified care workers in Japan. Health care workers who migrate to Japan under this program are designated as "candidates" until they pass the National Board Examination (NBE) conducted in the Japanese language for both nurses and certified care workers. ${ }^{3}$ While preparing for the NBE, the candidates are allowed to work as trainees at medical institutions and/or long-term care facilities in Japan. ${ }^{4}$

Migration is a process of social change whereby an individual moves from one cultural setting to another for the purpose of settling either permanently or for a prolonged period. A basic underlying theme in the existing literature linking migration and mental health is that the disruption of moving to a new environment can negatively affect health, including mental well-being, which may reducing the net benefit of migration. ${ }^{5,6}$ According to Berry, ${ }^{7}$ migration has been linked to a critical life event. Numerous studies on migration indicate that social adjustment during the process of migration is linked to mental illness, which may be influenced by various sociodemographic factors (sex, age, economic background) as well as socio-cultural adaptation, language barriers, social support, acceptance by the host community and conditions of employment. ${ }^{8-11}$

Migration affects the cultural and psychological change as a result of contact between two or more cultural groups and their individual members. The ability to adjust with the host country depends on their competency in socio cultural adaptation. Kirmayer et al, ${ }^{12}$ revealed that the mental health condition of migrants is linked to the capacity for socio-cultural adaptation, which may reflect the degree of acculturation and integration with the host country. Moreover, Bughra \& Becker, ${ }^{8}$ divided the migration process into three stages, namely pre-migration, migration, and post-migration. Each stage is potentially associated with mental health problems. Pre-mi- gration factors, such as the reason for joining migration, may contribute to how well the individual adjusts to cultural differences and subsequently influence the establishment process. ${ }^{13,14}$ The reason for migration may reflect the degree of willingness to migrate and resettle in a new environment, which may also influence the migrants' mental health. ${ }^{15}$ Additionally, post-migration conditions, such as working conditions, social support and competency in socio-cultural adaptation, have also been reported to be predictors of mental illness. ${ }^{11,16}$ Several studies related to the mental health conditions of migrant nurses and certified care worker under JIEPA program showed that some socio-cultural issues, including cultural stress, salary and reward issues, feelings of loneliness and the burden to passing the national board examination, are significant stressors faced by Indonesian nurse and certified care worker candidates in Japan. ${ }^{17,18} \mathrm{~A}$ longitudinal study on mental health condition of the Economic Partnership Agreement (EPA) candidates conducted by Kinkawa et al, ${ }^{19}$ revealed that the mental health condition of the eicosapentaenoic candidates worsened in six months after being deployed in the work field, compared to the condition at the time of Japanese language training conducted 6 months after they arrived in Japan.

A few studies have examined the changes in mental health status of EPA migrants' in pre-departure and after departure stage. This study examined the mental health condition in pre-migration and post-migration stages, and figure out the mental health changes as a result of migration. Moreover, this study aimed to identify the predictors that influence the mental health changes in the pre-migration and post-migration stages.

\section{Method}

This study was conducted in longitudinal design, which consists of twice measurement, namely baseline and follow-up study. Study was the sixth batch of Indonesian candidate nurses and certified caregiver who departed to Japan under JIEPA program in 2013, with a total 148 participants; total population were included in this study. The baseline survey was carried out during the pre-departure orientation in pre-migration period (June 2013 in Jakarta) and the follow-up survey was conducted one year after migration (June 2014 in Japan). This study assessed mental health as the outcome variable. Prior to the study, this study had passed ethical concern and been approved by the ethics committee of Nagasaki University (approval No.13041101, May 2013).

General Health Questionnaire (GHQ)-12 were selected to measure the subject's current mental health condition. ${ }^{20}$ The measurements focused on two major areas that are the inability to carry out normal functions and the onset of new and distressing experiences. ${ }^{21}$ The dif- 
ference in the score of GHQ-12 between the baseline and follow-up study was utilized to identify mental health changes. A positive score corresponded to an increasing in the GHQ score and was interpreted as meaning that the subject's mental health condition was worsening. The validity and reliability of the Indonesian version of the GHQ-12 has been confirmed, with a Cronbach's alpha of $0.670-0.776 .{ }^{21}$ The predictor variable consists of participant's socio demographic status (sex, age, EPA course), working condition (previous working background, working hours, fatigue, job satisfaction, satisfaction toward support given by preceptors, the extent of struggle against the current working condition), sociocultural adaptation scale (SCAS), and multidimensional scale perceive social support (MSPSS), current economic condition (pre-migration and post-migration).

The participants of the baseline study included the sixth batch of Indonesian EPA nurse and certified care worker candidates who departed in 2013 with a total of 148 participants. Respondents' rate for follow-up study was $62.1 \%$ (92 respondents were analyzed in this study). Informed consent for baseline and follow-up study participation as well as a personal contact address such as email was obtained. A seven-page questionnaire was distributed in the pre-migration.

In order to indentify the most appropriate model for this study, the analysis were carried out in the following stages, namely a descriptive analysis, independent sample t-test, paired sample t-test, and Pearson's correlation coefficient were seleceted for bivariate analysis. Furthermore, a multiple linear regression analysis was employed to determine the most appropriate model for the change in GHQ score.

\section{Results}

Table 1 shows the distribution of the sociodemographic characteristic of the study participants. The average age of study participants was 25.21 years old, $56.50 \%$ of the subjects were female. The percentage of certified care worker candidates was $69.70 \%$, compared to only $31.40 \%$ for nurse candidates. Regarding the working background of the candidates before applying to the EPA program, $60.90 \%$ of the candidates had previously worked as nurse and $39.10 \%$ had not. The language proficiency after migration showed $71.70 \%$ rate themselves as "intermediate".

Table 2 presents the mean difference of predictor variables between pre-migration and post-migration. With respect to the current economic conditions, it shows significant different between pre-migration and post migration. The mean SCAS and MSPSS scores showed significant differences between the pre-migration and postmigration periods, whereas the mean score of post-migration lower than the pre-migration mean score. The mean score of the GHQ-12 in pre-migration and post-migration did not show any significant difference. Hence,

Table. 1 Sociodemographic Characteristics and Variable Description

\begin{tabular}{|c|c|c|c|c|}
\hline Indicator & Category & Mean ( \pm SD Range) & $\mathbf{n}$ & $\%$ \\
\hline Age (M, SD, range) & & $25.21( \pm 2.36$, range $22-35)$ & & \\
\hline \multirow[t]{2}{*}{ Sex } & Male & & 40 & 43.5 \\
\hline & Female & & 52 & 56.5 \\
\hline \multirow[t]{2}{*}{ EPA course } & Nurse & & 28 & 31. \\
\hline & Certified care worker & & 64 & 69.6 \\
\hline \multirow[t]{2}{*}{ Working background in pre-migration } & Used to worked as nurse & & 56 & 60. \\
\hline & Never worked as nurse & & 36 & 39.1 \\
\hline \multirow{2}{*}{ Support given by the preceptor } & Not satisfied & & 17 & 18.5 \\
\hline & Satisfied & & 75 & 81.8 \\
\hline \multirow[t]{3}{*}{ The frequency of feeling physically fatigue } & Always & & 21 & 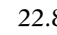 \\
\hline & Sometime & & 61 & 66.3 \\
\hline & Seldom & & 10 & 1. \\
\hline \multirow[t]{2}{*}{ Job satisfaction } & Not satisfied & & 22 & 23. \\
\hline & Satisfied & & 70 & 76.1 \\
\hline \multirow[t]{2}{*}{ Struggle against the current condition } & Yes & & 63 & 68.5 \\
\hline & No & & 29 & 31.5 \\
\hline \multirow[t]{4}{*}{ Japanese proficiency } & Beginner & & 1 & 1.1 \\
\hline & Elementary & & 23 & 25 \\
\hline & Intermediate & & 66 & 71.7 \\
\hline & Advance & & 2 & 2.2 \\
\hline The change in GHQ score & & $1.24( \pm 7.21 \mathrm{SD}$, range, $-17-17)$ & & \\
\hline The change in SCAS score & & $0.4( \pm 0.64$ SD, range- $1.1-2.48)$ & & \\
\hline The change in MSPSS score & & $6.03( \pm 13.01 \mathrm{D}$, range $-27-35)$ & & \\
\hline Working hours in a week & & $37.8( \pm 8.97 \mathrm{SD}$, range $12-63)$ & & \\
\hline Study hours & & $10.5( \pm 8.20 \mathrm{SD}$, range $0-32)$ & & \\
\hline
\end{tabular}

Notes:

$\mathrm{SD}=$ Standard Deviation, $\mathrm{n}=$ Number of Sample 
Table 2. Mean Score Difference between Pre-migration and Post-migration

\begin{tabular}{|c|c|c|c|c|c|c|}
\hline \multirow{2}{*}{ Description } & \multicolumn{2}{|c|}{ Pre-migration } & \multicolumn{2}{|c|}{ Post-migration } & \multirow{2}{*}{$\mathrm{t}$} & \multirow{2}{*}{ p Value } \\
\hline & Mean & SD & Mean & SD & & \\
\hline GHQ-12 & 24.48 & 4.73 & 25.73 & 5.57 & 1.67 & 0.098 \\
\hline MSPSS & 68.78 & 7.83 & 62.75 & 11.5 & -4.45 & 0.001 \\
\hline SCAS & 3.54 & 0.48 & 3.13 & 0.45 & -6.16 & 0.001 \\
\hline Current economic condition & 2.57 & 0.54 & 2.72 & 0.49 & 2.10 & 0.038 \\
\hline Very difficult to survive & \multicolumn{2}{|c|}{$2.20^{\mathrm{a}}$} & \multicolumn{2}{|c|}{$2.20^{\mathrm{a}}$} & & \\
\hline Difficult but able to survive & \multicolumn{2}{|c|}{$39.10^{\mathrm{a}}$} & \multicolumn{2}{|c|}{$23.60^{\mathrm{a}}$} & & \\
\hline Not so difficult to survive & \multicolumn{2}{|c|}{$58.70^{\mathrm{a}}$} & \multicolumn{2}{|c|}{$73.90^{\mathrm{a}}$} & & \\
\hline
\end{tabular}

Notes:

$\mathrm{SD}=$ Standard Deviation

Table 3. Correlation Coefficient between GHQ Score Changes and Predictor Variables

\begin{tabular}{lcc}
\hline \multicolumn{1}{c}{ Variables } & $\mathbf{r}$ & $\mathbf{p ~ V a l u e}$ \\
\hline Age & 0.073 & 0.491 \\
Working hours & 0.213 & 0.044 \\
Study hours & 0.016 & 0.883 \\
SCAS score difference & -0.366 & 0.001 \\
MSPSS score difference & -0.352 & 0.001 \\
Economic condition in post-migration & -0.148 & 0.155 \\
Economic condition in pre-migration & -0.288 & 0.029 \\
Satisfaction toward support given by the preceptor & -0.287 & 0.006 \\
Fatigue & -0.359 & 0.001 \\
Job satisfaction & -0.247 & 0.001 \\
The extent of struggle against the current condition & -0.282 & 0.001 \\
Self-rated Japanese language proficiency in post migration & -0.201 & 0.055 \\
\hline
\end{tabular}

Notes:

$\mathrm{r}=$ Correlation

Table 4. The Prediction Model of Mental Health Changes

\begin{tabular}{|c|c|c|c|c|}
\hline \multirow{2}{*}{ Variables } & \multicolumn{2}{|c|}{ Unstandardized regression coefficient } & \multirow{2}{*}{$\begin{array}{c}\text { Standardized } \\
\text { regression coefficient } \\
(\beta)\end{array}$} & \multirow{2}{*}{ p Value } \\
\hline & $\beta$ & SE & & \\
\hline Sex & 2.917 & 1.392 & 0.201 & 0.039 \\
\hline Age & .404 & .411 & 0.119 & 0.329 \\
\hline EPA course & 1.539 & 1.889 & 0.099 & 0.418 \\
\hline Satisfaction toward support given by preceptor & -.868 & 1.158 & -0.087 & 0.456 \\
\hline Working hours & .048 & .092 & 0.060 & 0.604 \\
\hline Fatigue & -1.865 & 1.385 & -0.146 & 0.182 \\
\hline Job satisfaction & .133 & 1.423 & 0.010 & 0.926 \\
\hline The extent of struggle against the current condition & -1.195 & 1.157 & -0.103 & 0.305 \\
\hline Working background before migration & 0.099 & 0.064 & 0.141 & 0.130 \\
\hline Economic condition in pre- migration & -2.684 & 1.252 & -0.200 & 0.035 \\
\hline SCAS Score change & -2.671 & 1.183 & -0.238 & 0.027 \\
\hline MSPSS Score change & -0.111 & 0.059 & -0.200 & 0.064 \\
\hline
\end{tabular}

Notes:

$\mathrm{SE}=$ Standard Error

the different score of the GHQ score was selected to determine the change in the participant's mental health condition from before to after migration.

The bivariate analysis (Table 3) showed significant correlations between the change in the GHQ score and the change in the SCAS score $(\mathrm{r}=-0.366$, $\mathrm{p}$ value $<$ $0.01)$, fatigue $(r=-0.359, p$ value $<0.01)$, change in the
MSPSS score $(r=-0.352, p$ value $<0.01)$, economic conditions in the pre-migration period $(r=-0.288$, $p$ value $<$ $0.05)$, satisfaction with the support given by the preceptor $(r=-0.287, p$ value $<0.01)$, extent of struggle against the current conditions $(\mathrm{r}=-0.282$, $\mathrm{p}$ value $<0.01)$, job satisfaction $(\mathrm{r}=-0.247, \mathrm{p}$ value $<0.01)$ and working hours $(r=0.213$, $p$ value $<0.05)$ 
All variables showing significant correlation with the GHQ-12 and all demographic variables were combined to develop a model that predicted the mental health change using a multiple linear regression analysis. Based on Table 4, the prediction model was statistically significant, $\mathrm{F}=4.212$, $\mathrm{p}$ value $<0.01$, and accounted for approximately $39.90 \%$. The different score of SCAS received a strongest weight in the model $(\beta=-0.238)$, followed by sex $(\beta=0.201)$, and economic condition in premigration period $(\beta=-0.200)$.

\section{Discussion}

In this study, showed that the changes in the mental health status of EPA nurse and certified care worker candidates in pre-migration and post-migration were predicted by the competency in socio-cultural adaptation gender (female) and having economic constrain in pre-migration.

This study identified the change in SCAS score as the strongest predictor for the mental health change. The result in independent sample t-test also showed that the SCAS score was significantly decrease after migration. The decreasing score was refer decreasing in socio-cultural adaptation competency. According to Ward \& Kennedy, ${ }^{22}$ socio-cultural adaptation refers to the ability to fit in or effectively interact with members of the host culture. The cultural distance between Indonesia and Japan, required an appropriate competency in adapting with language, culture, social status and social interaction to fit in with the host country's socio-cultural setting. The score difference between in pre- and post-migration assumes that there was discrepancy between expected competency and the actual competency in socio-cultural adaptation. The study participants tend to face difficulties in post-migration. On the other hand, their adaptability was below their estimation. Migration allowed the migrants facing several changes practically everything that surrounds the person. This situation may raise psychological distress among the migrants. Competency in socio-cultural adaptation positively correlate with healthier mental health. ${ }^{23}$ This study showed that decrease in competency to adapt with socio-cultural difference was strongly correlated with the poorer mental health.

Sex was identified as the significant predictor that influences the change in GHQ score according to the multiple linear regression models. This finding was in line with previous study in migration (24-26) which revealed that the female migrants likely have poorer mental health than the males. Nevertheless, further examination regarding distinct migrants' background need to be assessed. The participants of this study migrated alone, most of them were not married and they received equal treatment regardless of sex, under the JI-EPA program. The sex issues which raises in this study may be rotted by the nature of the difference in perceived stressor and pro- tective factor among male and female migrants. This study showed that the female migrant, tend to have poorer psychological well-being. Although women's social empowerment in society is well-received, but the role and social relations of the sex are not equal. ${ }^{27}$ Additionally, separation with the sources of social support, such as family members and others, may result in declining mental health. Compared to the male candidates, female with lack of social support, who are exposed to stressful life events, such as migration, are more vulnerable with psychological disorder than male. ${ }^{26,28-30}$ The socio-cultural background of the female candidates, which is rooted in their culture of origin, including the patriarchal system in Indonesia may also explain this study finding. The patriarchal system, whereby the man remains the head of household and is expected to act as the decision maker and be responsible for the other family members, is in place in most parts of Indonesian people. According to Herdman \& Srivastava, ${ }^{31}$ the patriarchal foundation dominates Indonesian people, even among the most liberal and globalized citizens. Despite the fact that Indonesian women currently have equal opportunities to males, as applied in the EPA program, the patriarchal concept continues to dominate when making decisions regarding the candidates' future. Female candidates are not able to easily and freely decide their future without receiving permission from their father or spouse. This situation may lead the occurrence of the internal conflict in female candidates and affect their mental health condition.

The current study found that the economic conditions in the pre-migration period exhibit a significant correlation with the change in the GHQ score, and there is a tendency toward declining mental health after migration among those living with lower economic conditions in the pre-migration period. Those who come from poorer economic condition are possibly burdened with the condition of their family left behind. They express responsibility to their family by sending their revenue to support their family economically. This finding is in accordance with a study conducted by Hirano among Filipinos migrants in Japan, which revealed that those who come from poorer economic condition tend to have poorer mental health. ${ }^{32}$ High living expenses in Japan may less favorable for individuals coming from poorer economic conditions. These migrants have spent their income on their daily living costs as well as sending money back home to their family. This finding indicates that the obligation to remit their income reduces their disposable income and thus hinders improvements in their well-being due to living in improved economic conditions following migration. Another assumption is that migrants with economic constraints are less likely to enjoy life in Japan. On the other hand, those who have better economic condi- 
tions are able to spend their revenue more freely and enjoy their life in Japan.

The findings of this study are expected to become an input for both sending and receiving countries of the migrants, especially in the evaluation of the program implementation. Most often, migration is linked to stressful events, including barriers and challenges, as well as psycho-social issues. Therefore, appropriate approaches and preventive strategies such as optimizing the pre-departure process should be discussed. Providing felicitous information about working and living environment is effective to help the candidates adapting with their new working field. This is particularly true, when these information is provided through EPA returnees, by sharing their experience while working in Japan, so that the successors will physically and mentally well prepare.

The results of this study need to be considered in the context of their limitation. The limited number of participants in post-migration study $(62 \%)$ may result the non-response bias. These finding only represent the situation in the first year of migration, therefore, the trends in mental health change and its predictor over time were not assessed. Further study is recommended to determine the overall trends in and predictors of mental health changes.

\section{Conclusion}

The present longitudinal study is conducted to identify predictors of mental health changes from the pre-migration to post-migration stages. The multiple linear regression model developed in this study indicated that the SCAS score is the strongest indicator of mental health, followed by sex and the economic conditions in the premigration period. The current results indicate the importance of developing a system to help Indonesian candidates adjust to the new culture one year after migrating to Japan. This study must be followed up with further study to clarify the long-term trends in mental health changes among the respondents.

\section{Acknowledgment}

This study is made possible by study grant administrated by the Japan Society for the Promotion of Science (JSPS) under the study title of 'Introducing foreign nurse and certified care workers under the bilateral agreement: Friction and Cohabitation' (Representative: Dr. Yuko Ohara-HIRANO) funded by KAKENHI (Grant-in-Aid for Scientific Study (B)26293113, fiscal years 20142018)

\section{References}

1. United Nation Foundation for Population Activity. International migration 2013 international migration 2013. 2013. p. 1-414. Available from: http://www.unfpa.org/migration\#sthash.kVMdlok7.dpuf
2. Kingma M. Nurse migration: mini-business, big business. Harvard policy Review. 2006; 7(1): 102-12. Available from: http://hhpronline.org/ wp-content/uploads/2012/05/Kingma.pdf

3. Ministry of Health labor and Welfare J. Accepted framework that is based on the economic partnership agreement Keizai renkei kytei ni motodzuku ukeire wakugumi. 2014. p. 0-4. Available from: http://www.mhlw.go.jp/file/06-Seisakujouhou-11650000Shokugyouanteikyokuhakenyukiroudoutaisakubu/epa_gaiyou.pdf

4. Kementrian Perdagangan Republik Indonesia DGIT. Indonesia-Japan economic partnership agreement international cooperation. 2007. p. 1-5. Available from: http://ditjenkpi.kemendag.go.id/website_kpi/index.php?module=news_detail\&news_category_id=5

5. Bhugra D. Migration and mental health. Acta Psychiatrica Scandinavica 2004; 109: 243-58. Available from: http://onlinelibrary.wiley.com/doi/ 10.1046/j.0001-690X.2003.00246.x/full

6. Stillman S, Mckenzie D, Gibson J. Migration and mental health: evidence from a natural experiment 2006. Report No. 123. Available from: http://poverty-action.org/sites/default/files/wps4138.pdf

7. Berry JW. Immigration, acculturation adaptation. Applied Psychology An International Review. 1997; 45(1): 5-68. Available from: http://isites.harvard.edu/fs/docs/icb.topic1063337.files/immigrationacculturtion Reading.pdf

8. Bughra D, Becker MA. Migration, cultural bereavement and cultural identity. World Psychiatry. 2005; 4(1): 18-24. Available from: http://www.ncbi.nlm.nih.gov/pmc/articles/PMC1414713/

9. Vega W a, Kolody B, Valle JR. Migration and mental health: an empirical test of depression risk factors among immigrant Mexican women. In: The International Migration Review [Internet]. 1987. p. 512-30. Available from: http://www.ncbi.nlm.nih.gov/pubmed/12314896

10. Tinghong P. Migration, stress and mental ill health - post migration and factors experience in the Swedish Context Linkoping University; 2009. Available from: http://liu.diva-portal.org/smash/get/diva2:216798/ FULLTEXT01.pdf

11. Apprahamian M, David M, Amy M, Judith A. The relationship between acculturation and mental health of Arab Americans. Journal Mental Health Counseling. 2011; 33(1): 80-92. Available from: http:// www.studygate.net/profile/J_Visser/publication/224861971_The_relationship_between_acculturation_and_mental_health_of_ArabAmericans/links/0912f4f9fc81613f2f000000.pdf

12. Kirmayer LJ, Narasiah L, Munoz M, Rashid M, Ryder AG, Guzder J, et al. Common mental health problems in immigrants and refugees: general approach in primary care. Canadian Medical Association Journal. 2011 Sep 6 [cited 2014 Apr 30]; 183(12): E959-67. Available from: http://www.pubmedcentral.nih.gov/articlerender.fcgi?artid $=3168672 \&$ tool $=$ pmcentrez\&rendertype $=$ abstract

13. Burgelt PT, Morgan M, Pernice R. Staying or returning?: pre-migration influences on the migration process of german migrants to New Zealand. Journal of Community Applied Social Psychology. 2008; 18(March 2007): 282-98.

14. Yijälä A. Pre-acculturation among voluntary migrants. University of Helsinki, Finland; 2012. Available from: https://helda.helsinki.fi/bitstream/handle/10138/33527/preaccul.pdf?sequence=1

15. Maydell-stevens E, Masgoret A, Ward T. Problems of psychological and sociocultural adaptation among Russian-speaking immigrants. Social 
Policy Journal New Zealand. 2007; (30): 178-98. Available from: Problems of Psychological and Sociocultural Adaptation Among Russian-Speaking Immigrant

16. Berry JW. Acculturation: living successfully in two cultures. International Journal Intercult Relations. 2005 November [cited 2014 July 14]; 29(6): 697-712. Available from: http://linkinghub. elsevier.com/retrieve/pii/S014717670500132X

17. Alam B, Wulansari SA. Creative friction: some preliminary consideration the socio-cultural issues encountered by indonesian nurses in Japan. Bulletin of Kyushu University Asia Center. 2010: 5; 183-92.

18. Setyowati, Susanti H, Yetti K, Ohara-Hirano Y, Kawaguchi Y. The experience of indonesian nurse in japan who face the job and cultural stress in their work: a qualitative study. Kyushu University Institutional Repos. 2010; 5: 175-81. Available from: kyoto-seas.org/wpcontent/uploads/2012/07/490405.pd

19. Kinkawa M, Hapsari ED, Ueda M, Hiroya M. Current situation and challenge in employment of indonesian nursing/certified care worker candidates based on economic partnership agreement between Indonesia and Japan. Bulletin of Health Science Kobe. 2012; 28: 31-40. Available from: http://www.lib.kobe-u.ac.jp/handle_kernel/81004829

20. World Health Organization. Investing in mental health. 1st edition. Lee J-W, editor. Geneva: Depatment of Mental Health and Substance Dependence World Health Organization; 2003.
21. Idaiani S, Suhardi S. Validity and reliability of the general health questionnaire for psychological distress and social dysfunction screening in community. Bulletin of Health Research. 2006; 34(4): 161-73. Available from: http://bpk.litbang.depkes.go.id/index.php/BPK/article/ view/1204

22. Ward C, Kennedy A. Psychological and socio-cultural adjustment during cross-cultural. 1993; 28: 129-47. Available from: http://onlinelibrary.wiley.com/doi/10.1080/00207599308247181/pdf

23. Zhao L. Socio-cultural adjustment of international students as expatriates in America. Kentucky: Western Kentucky University; 2010.

24. Asakura T, Murata AK. Demography, immigration background, difficulties with living in Japan, and psychological distress among Japanese Brazilians in Japan. Journal Immigrant Minority Health. 2006 Oct [cited 2014 May 13]; 8(4): 325-38. Available from: http://www.ncbi. nlm.nih.gov/pubmed/16732436

25. Ikeguchi C. Intercultural adjustment - reconsidering the issues: the case of foreigners in Japan. Intercultural Communication Studies. 2007; XVI: 99-109. Available from: http://www.uri.edu/iaics/content/2007v16n3/ 08 Cecilia Ikeguchi.pdf

26. Mahmud SH, Masuchi A. Foreign residents in japan: Acculturation, social connectedness, and life satisfaction. Psychological Research. 2013; 3(12): 737-48. Available from: http://www.davidpublishing.com/ davidpublishing/Upfile/1/20/2014/2014012081953481.pdf 